\title{
Land-use experts' perception of regional climate change: an empirical analysis from the North German Plain
}

\author{
Tim Barkmann ${ }^{1} \cdot$ Rosemarie Siebert $^{1} \cdot$ Andrej Lange $^{1}$
}

Received: 9 December 2016 / Accepted: 24 July 2017 / Published online: 8 August 2017

(C) The Author(s) 2017. This article is an open access publication

\begin{abstract}
The impact of climate change on a variety of scales and on land-use policies across sectors is well-established. There will be climate-related changes to which land use must adapt, although Europe and Germany may not be as affected as other regions. Therefore, we must evaluate how climate change is perceived on a regional scale and across land-use sectors. The aim of this study is to gather information from regional land-use experts regarding their perceptions of climate change to highlight the impact of climate change on land use and to identify the risks and opportunities associated with climate change that these experts observe. With these objectives in mind, we conducted 60 semi-structured interviews and a questionnaire survey with regional land-use experts in agriculture, forestry, and water management in four case study regions in the North German Plain. Climate change is clearly acknowledged by the experts throughout the regions and across the sectors. Drought (particularly in the spring) and increased occurrences of extreme weather events are the most severe regional issues identified. Furthermore, with very few exceptions, climate change is mostly understood as a risk. The results of this study confirm the results from other models and prognoses but with more detail and precision at the regional level. Differences among the sectors and regions were also noted. Unlike most studies, the regional experts in our sample have already noted the impacts and risks of climate change cross-sectorally, which might be a good basis from which to begin regional adaptation.
\end{abstract}

Keywords Stakeholder · Qualitative approach · Land management · Climate change impacts · Risk perception

Electronic supplementary material The online version of this article (doi:10.1007/s10584-017-2041-x) contains supplementary material, which is available to authorized users.

Tim Barkmann

tim.barkmann@zalf.de

1 Institute of Socio-Economics, Leibniz Centre for Agricultural Landscape Research, Eberswalder Straße 84, 15374 Müncheberg, Germany 


\section{Introduction}

The existence of climate change - and its (at least) partial basis in anthropogenic causes (IPCC 2013) - is well-established (Hansen et al. 2012). Changes in climate can already be confirmed at the regional level in Germany (Gerstengarbe and Werner 2007). Although the expectations are that Germany may not be as affected by climate change as other regions or countries (Bindi and Olesen 2011; Wheeler et al. 2013), there are nonetheless environmental changes anticipated in Germany due to global climate change, and analyses of regional climate change should thus be taken seriously because even small changes may have strong effects on ecosystems (Leemans and Eickhout 2004). Various simulation techniques have evolved the capability to simulate climate change not only on a global scale but also on a regional (Europe and Germany - Gerstengarbe and Werner 2007) and even on a local scale (BrandenburgGerstengarbe et al. 2003) with a corresponding increase in uncertainty. In addition to approaches that employ various models and simulations at different depths to model climate change, other approaches analysing public perception and expert perception play a role in current attempts to understand, describe, or approximate climate change and global warming. We have good insight into the views of lay people and the general public regarding global climate change at the national level (Lorenzoni et al. 2007; Whitmarsh 2011; Agho et al. 2010; Engels et al. 2013), in addition to studies with a more global perspective (Lorenzoni and Pidgeon 2006; Kvaløy et al. 2012). Some of these perceptions are analysed in more detail, such as how the public's view on climate change has changed over time (Whitmarsh 2011; Ratter et al. 2012), whether certain outside influences affect this perception (Scruggs and Benegal 2012) and whether climate change is perceived as a human health risk (Akerlof et al. 2010).

Expert opinions are also investigated in the literature. Those studies involving expert views on climate change frequently focus on a single issue, such as rapid climate change (Arnell et al. 2005), or the development of a definition (de Franca Doria et al. 2009). Studies of climate change and land use can generally be found in a broad variety and frequently involve developing adaptation strategies. Rounsevell and Reay (2009) analyse the relationship between land use and climate change, Rannow et al. (2010) focus on adaptation activities in spatial planning and their potential impact in Germany, whereas Reyer et al. (2012) connect adaptation with regional development. Furthermore, the impacts of climate change on ecosystems in general (Leemans and Eickhout 2004), on forests (Lasch et al. 2002), and/or on agriculture and water management (Falloon and Betts 2010) are also analysed and are frequently linked to adaptation. Even cross-sectoral analyses can be found regarding adaptation strategies (Reyer et al. 2012).

Orienting our analysis to climate change perception while remaining in the field of land use, highly specialised studies can e.g. be found in viniculture (Battaglini et al. 2009) and agriculture (Jørgensen and Termansen 2016); nonetheless, cross-sectoral approaches are not common. Moving our focus to Germany at the regional level, there are a few studies regarding forestry (Lasch et al. 2002; Kätzel and Höppner 2011), forestry, agriculture, water management, and conservation (Reyer et al. 2012) in the State of Brandenburg as a region of interest or on public perception of climate change in Hamburg (Ratter et al. 2012). Thus, whereas analysing the perception of climate change in Germany is limited to the general public, there are no cross-sectoral approaches that consider the perception of climate change. As Rannow et al. (2010) note, "Climate change is a global concern but the effects will be felt and dealt with on a regional or even local level. Hence, they must be analysed and addressed against this background." Furthermore, Falloon and Betts (2010) suggest that a cross-sectoral approach 
may be required that considers future risks regarding the interconnectedness of agriculture and water management, whereas Laukkonen et al. (2009) conclude, "It is acknowledged that climate change is a global phenomenon that impacts societies throughout different scales: from individuals to localities and entire regions." Thus, the perspectives of landowners and those using the land at a regional level must be considered. Moreover, implementing specific strategies without the participation of such regional actors (and certainly without their consent or against their wishes) would be difficult — if not impossible - as has been experienced in implementing flood plains or dike relocating. In forestry, in particular, studies emphasise the anticipated effects of climate change (Lindner et al. 2010; Lasch et al. 2002; Kätzel and Höppner 2011), and it can be understood that there is a high degree of stakeholder responsibility for engaging in the long-term planning that is necessary for maintaining the timber industry (Kätzel and Höppner 2011). Thus, immediate implementation of action based on sound advice would be hard to find regardless of a given study's quality, and self-legitimation highly depends on the perception of individuals or groups in the affected regions.

Adger et al. (2009) posit that adaptation decisions depend on the perceptions of risk held by society that may act as a limiting factor. Moreover, risk perception requires knowledge as basis for the development of a better understanding of the issue in question (Stoutenborough et al. 2013). Therefore, we argue that it is important to know how climate change is perceived in a sector or region before developing adaptation strategies for that sector or region.

Considering the lack of information and knowledge about perceptions of land-use experts regarding climate change, on the one hand, and the need to address climate change at the regional and local levels, on the other hand, this study fills this gap by analysing the perception of climate change by land-use experts at the regional level using a cross-sectoral approach. In this study, we thus aim to achieve the following: (1) gather information regarding the general perception by regional land-use experts on climate change at the regional level, (2) highlight the perceived impacts of climate change on land use, and (3) note the risks and opportunities that are perceived by experts associated with climate change.

\section{Research area}

We choose a case study approach, and our case study region is the North German Plain, which includes the four nested regions of Diepholz, Uelzen, Flaeming, and Oder-Spree on a west-east transect (Supplementary material). The North German Plain covers the northern part of Germany stretching from the North Sea and the Baltic Sea in the north to the Central German Uplands in the south. The climate zone changes along the transect shift from temperate oceanic (Cfb) to humid continental (Dfb) with declining precipitation. Furthermore, there is a pattern of declining amounts of land utilised as pasture for livestock farming moving from west to east, whereas the percentage of arable land and forests increases along with farm size. In addition to aspects of land use, the socioeconomic aspects along the transection vary in the movement from west to east: economic power and population density decline, whereas the average age of the population increases.

The regional land use in the administrative district of Diepholz is dominated by a high percentage of agricultural land (75\%). This region has very little forest area (9\%) and a significant percentage of fens. The average mean temperature is $9.6{ }^{\circ} \mathrm{C}$, and the average annual (summer) precipitation is 699 (204) $\mathrm{mm}$. The vegetation period lasts approximately 173 days. In the Uelzen region, $53 \%$ of the land is agricultural, and $34 \%$ of the area consists of 
forests. Irrigation is very important in this region, and approximately $90 \%$ of the arable land is irrigable. The average mean temperature is $9.0{ }^{\circ} \mathrm{C}$ and the average annual (summer) precipitation is $733(214) \mathrm{mm}$. The vegetation period lasts approximately 168 days. Land use in the Flaeming region is dominated by forests (42\%) with a high percentage of pine trees and large-scale farming. The average mean temperature is $9.5^{\circ} \mathrm{C}$, and the average annual (summer) precipitation is $554(171) \mathrm{mm}$. The vegetation period lasts approximately 176 days. The land-use structure in the Oder-Spree region is also dominated by forests (45\%) and large farms (35\% agricultural). Furthermore, two large rivers (the Spree and Oder) flow through the region. The average mean temperature is $9.2{ }^{\circ} \mathrm{C}$, and average annual (summer) precipitation is $570(182) \mathrm{mm}$. The vegetation period lasts approximately 175 days. Additional details are provided in Barkmann et al. (2015) and Lange et al. (2015).

\section{Material and methods}

Because there is little knowledge about the perceptions of regional land-use experts regarding regional climate change, we addressed this issue through an explorative approach (Babby 2012; Cresswell 2009) as part of a larger study addressing sustainable land use and land use change at the regional level in the four research regions. According to Patton (2002), this type of approach is common in developing new fields of research. We used a mixed methods design, in which we (a) conducted 60 qualitative interviews with regional land-use experts from the agriculture, forestry, and water management sectors, in addition to "cross-sector experts", and (b) used a questionnaire to obtain additional information from our sample. As Pidgeon (2012) notes, there is considerable value in employing a mixed-methods. The results presented in this paper are primarily based on the qualitative interviews conducted in the four case study regions. To gather high-quality information, we selected regional land-use experts (Meuser and Nagel 1991). The identification of experts was primarily based on the criteria of legitimacy, resources, and interconnectedness (Zimmermann and Maennling 2007). We selected the sample with a strong focus on those land-use sectors that might be affected by climate change. We identified experts in these sectors using the support of regional project partners and snowball sampling (Miles and Huberman 1994). In a first step, our regional project partners recommended the initial experts. In the interviews, we asked them to recommend further experts with whom we should speak. Our experts came from farmers' associations, forest administrations, water body maintenance associations, planning administrations, environmental administration, NGOs, LEADER management, and nature conservation. The final list of organisations from which experts were interviewed is provided in Table 1, and a full list of experts is provided in the Supplementary material. Due to a careful selection and the use of regional project partners in the regions (Lange et al. 2016), we were able to conduct interviews with all of the identified institutions.

a) All interviews were conducted face-to-face in a semi-structured manner at the interviewees' offices between January 2011 and January 2012. Face-to-face interviews allow a wide range of topics regarding climate change to be covered. Furthermore, the interviews were flexible and their face-to-face nature ensured that the professional perspective 
Table 1 Land use sectors and expert groups represented in the study

\begin{tabular}{|c|c|c|}
\hline $\begin{array}{l}\text { tbcolw } 70 \text { ptLand } \\
\text { use sector }\end{array}$ & tbcolw210ptExpert groups represented & $\begin{array}{l}\text { No. of } \\
\text { experts }\end{array}$ \\
\hline Agriculture & $\begin{array}{l}\text { Regional farmers' associations, regional agricultural administration, farm } \\
\text { managers, irrigation association }\end{array}$ & 14 \\
\hline Forestry & $\begin{array}{l}\text { Regional forest administration, forest managers, hunters' association, state } \\
\text { forest administration }\end{array}$ & 11 \\
\hline Water management & $\begin{array}{l}\text { Water supply companies, regional water body maintenance associations, } \\
\text { regional administration for water resource management and coastal } \\
\text { protection, irrigation association }\end{array}$ & 14 \\
\hline Cross-sector & $\begin{array}{l}\text { Regional planning administrations, regional tourism associations, regional } \\
\text { environmental administration, environmental protection NGOs, regional } \\
\text { LEADER management, nature conservation authorities }\end{array}$ & 21 \\
\hline
\end{tabular}

and the complexity of the climate change issues were adequately reflected because clarification and recognition techniques were employed (Patton 2002). To improve the quality of the interviews, all interviewees were given an outline of a guideline to prepare prior to the interview. The questions regarding climate change included the following: (1) "How is your work influenced by the climate change discussion?," (2) "Can you already perceive climate change impacts in your region?," and (3) "What part might climate issues play in future land use?"

All interviews were recorded and fully transcribed. After storing the transcripts in the project database, the interviews were coded and analysed using the MAXQDA 10 software tool for qualitative data analysis. The general coding structure followed the interview guidelines, whereas the subcoding was developed from the information given in the interviews. For the analysis, we used the content analysis method (Patton 2002).

b) Exploratory approaches require qualitative sampling and qualitative analytical procedures; however, because it is possible to include quantifications when they are meaningful and appropriate (Mayring 2000), we also used a questionnaire (See Supplementary material) to gather additional information regarding specific subjects and to quantify certain issues. The questionnaire was designed based on the interviews and consisted of closed-ended questions to complement given information and open-ended questions to acquire new information. Because the objective was to complement the interviews, the questionnaire and interviewee samples were identical. The questionnaire was sent to all 60 interviewees subsequent to the interviews. Thirty-seven interviewees filled in the questionnaire (agriculture, seven; forestry, nine; water management, seven; and cross-sector, 14) resulting in an overall response rate of $62 \%$.

The questionnaires were digitalised and analysed in a qualitative manner. This paper's analysis focused on which aspects of climate change were perceived in the regions, which were the most severe and which impacts could already be observed. Furthermore, we collected information regarding whether climate change is expected to entail opportunities or risks. The full questionnaire can be found in the Supplementary material, including questions not analysed for this paper. 


\section{Results and discussion}

The following section is structured into three parts. First, we present perceived climate change, including experts' views on the most severe issues. Second, we name the previously perceived climate change impacts. Third, we present the perceived risks and opportunities. In each part, data from the questionnaires supplement our information, and we discuss the results.

\subsection{Perceived climate change by land-use experts in the North German Plain}

Most of the experts (44) stated in the interviews that they perceived climate change or climatechange-related changes in their region. Only a few experts (6) noted that they perceived no climate-change-related changes or that the perceived changes were unrelated to climate change. Interestingly, even those who are uncertain about regional climate change impacts mention that they believe in global climate change. These results are supported by the respondents' answers to the questionnaire in all the regions examined - in which 27 out of 37 respondents indicated that they perceived climate change impacts in their regions, with five indicating that they did not perceive climate change impacts. Five respondents indicated that they did not know whether they perceived climate change impacts. Approximately one half of the experts indicated that they perceived the occurrence of more frequent extreme weather and climate events, and that these were becoming more intense, such as heavy or torrential rain in the summer after a long drought or heavy storms with changing directions. Other experts believed that those events did not occur more frequently than in the past but that they were more intense.

The experts generally perceived less precipitation, a trend towards aridity during spring and summer with almost drought-like water shortages during springtime, and a trend towards more precipitation in autumn and winter. In addition, extreme weather events characterised by torrential rain were widely perceived. While there is consensus among the experts on certain features of perceived climate change, certain sectoral-specific aspects were also revealed.

The perceptions are the same for most sectors, but they vary in precision, particularly with respect to a more sectoral view from experts with certain sectoral affiliations. Agricultural experts strongly focus on water shortages in the growing season, persistent drought periods in the spring, and torrential rain events following pronounced droughts. Additionally to the decreasing precipitation in summer, forestry experts point out that the spring drought periods tend to begin earlier in the season (formerly in May, currently as early as April) and that they perceive an increasing number of unusual weather phenomena, including local storm events with unusual wind directions. Water management experts further specify the shift of precipitation towards the winter, which became wetter while decreases in precipitation, especially in the eastern regions lead to groundwater levels substantially below mean levels.

Even with those sectoral differences, most of the experts' (44) perceptions regarding climate change impacts relate in one way or another to water and precipitation. Thus, most experts perceive that precipitation has shifted towards the winter and a correlated summer drought. Consistent with the precipitation shift, extended drought periods were observed, particularly at other times of the year, such as the spring. These long-term fluctuations are expected to become more common and lead to flooding in certain areas. Furthermore, most experts note that extreme weather events with torrential rains are also a problem. Thus, extreme weather events with heavy rainfall over short periods of time were also perceived by most experts. 
Corresponding to the interviews and widely matching those results, the most frequent answers to the questionnaire regarding concrete perceived changes in regions included increases in extreme weather, drought in the summer, torrential rains and (thunder) storms, high summer temperatures, and drought in the spring. In summary, the summer and spring droughts receive the most attention; therefore, the importance of water throughout the regions is emphasised (Table 2).

The number of indications regarding "high summer temperatures" in the questionnaire (12) differs substantially from the number of interviews in which summer temperatures were discussed (four). Although the category high summer temperatures is as important in the questionnaire as "torrential rain and storms," few experts note that increasing temperatures in summer are an issue during the interviews.

In addition to perceived climate changes, the experts' opinions regarding the severity of these changes are of high importance. Most experts (40) discussed drought, water scarcity in general, and water shortage or pronounced droughts in springtime, in particular, as very important issues. The issues were noted with little difference among sectors. Experts from the agricultural sector added decreasing precipitation in spring and short-term weather extremes with heavy rainfall to the list of important issues, whereas forestry sector experts considered drought in summer as a severe issue. In addition, storm events were noted. Additionally, water management experts consider drought to be the most severe feature but without further distinction. Furthermore, torrential rains also cause problems in addition to decreasing amounts of precipitation. The other experts recognise water scarcity in spring and summer as a severe and growing problem, in addition to torrential rains.

In the questionnaire, the severity of concrete climate change observations was also inquired about. In connection with the questions regarding concrete climate change, the respondents were asked to name the most severe change they perceived (Table 2). The results are almost identical to the concrete changes that further emphasise the drought. Focused on those drought-related answers, the survey reveals that by far the most important issue regarding the perceived climate change is drought in connection with water scarcity, which coincides with the experts' discussions in the interviews.

Most of the literature on climate change perception or climate change observation concludes that climate change impacts are already perceived and focuses on general climate change information. Whereas information regarding awareness or concerns about climate

Table 2 Perceived climate changes on the regional scale (multiple answers possible) and the most severe issues (open field-multiple answers possible) $(N=37)$

\begin{tabular}{llll}
\hline Perceived climate change & $\sum$ & Most severe Issue & $\Sigma$ \\
\hline Increase of extreme weather $^{\mathrm{a}}$ & 20 & Drought (spring) $^{\mathrm{b}}$ & 14 \\
Drought (summer) $^{\mathrm{a}}$ & 17 & Drought (summer) $^{\mathrm{b}}$ & 10 \\
Torrential rain and (thunder)storms $^{\mathrm{b}}$ & 13 & Drought (in general) $^{\mathrm{b}}$ & 8 \\
High summer temperatures $^{\mathrm{a}}$ & 12 & Torrential rain and (thunder)storms $^{\mathrm{b}}$ & 5 \\
Drought (spring) $^{\mathrm{b}}$ & 9 & Hot summer $^{\mathrm{b}}$ & 2 \\
Increase winter precipitation $^{\mathrm{a}}$ & 8 & Flood $^{\mathrm{b}}$ & 2 \\
Mild winter $^{\mathrm{a}}$ & 5 & Changed wind direction $^{\mathrm{b}}$ & 1 \\
Wet spring $^{\mathrm{a}}$ & 1 & Late frost $^{\mathrm{b}}$ & 1 \\
None at all $^{\mathrm{a}}$ & 0 & Wet autumn $^{\mathrm{b}}$ & 1 \\
\hline
\end{tabular}

\footnotetext{
${ }^{\text {a }}$ Predefined categories

${ }^{\mathrm{b}}$ Open field answers
} 
change or global warming is frequently presented (Kvaløy et al. 2012; Agho et al. 2010), there is little detailed information regarding the regional or cross-sectoral aspects of climate change. The climate change perception that is generally described is shared by most of our experts, however. Although some studies note a recent increase in climate change scepticism (Ratter et al. 2012; Whitmarsh 2011), others do not. Poortinga et al. (2011) indicate that climate change scepticism in the UK is not widespread. Engels et al. (2013) show the same for Germany and further conclude that the majority of the German public believes in the existence of climate change. Because the experts who are not sure whether climate change can be perceived come from all sectors, a sector-specific view can be excluded on this point. Because even those who are uncertain about regional climate change believe in global climate change, general climate change scepticism can also mostly be excluded. Following an explorative approach, we were able to reveal detailed information on perceived climate change. Our results are mainly consistent with those described by Taylor et al. (2014), who conclude that people from moderate climates (in their case, from the UK) focus on wet weather-related events, such as flooding and heavy rainfall. Focusing further on specific results that our experts noted, the literature regarding projections and climate modelling must be considered. The experts' observations of rising temperatures, increasing aridity - particularly in spring and summerwith constant or increasing precipitation in winter are also documented by Gerstengarbe et al. (2008) and Cubasch and Kadow (2011). Furthermore, the expected frequency and intensity of extreme weather are predicted to increase in the long term (Noleppa 2008), which was previously perceived by the regional actors in our sample, although the intensity - but not the frequency - of extreme events to date is perceived as increasing. Although the survey revealed, that increasing summer temperatures are perceived to some degree, only very few references to temperature were made at all in the interviews. The higher number of responses in the survey may be influenced by the fact that high summer temperatures were used as a predefined category. Although high temperatures were not considered to be of great importance during the interviews, the option seems to be important enough to be marked when given as a response option in a survey. However, this finding may indicate that even if there is an increase of annual mean temperatures, it might not be as important on the regional level as other events, such as decreases in precipitation during the growing season and/or extreme weather events. Taylor et al. (2014) arrived at similar conclusions with a focus on public climate perceptions in the UK and also note the importance of local weather-related events over general climate terms regarding engagement with mitigation and adaptation.

Regarding specific climate changes, such as drought, torrential rains, flooding, and extreme weather, the results of Battaglini et al. (2009) match ours to a large extent from the single features up to the trends. These authors also note "more frequent periods of drought across all seasons," which underlines our findings that drought, i.e. water scarcity, is one of the most serious problems accompanying climate change.

\subsection{Climate impacts on land-use}

Climate impacts on land use were perceived by our sample of experts based on their views about regional climate change. With regard to those impacts, land-use experts not only see the effects on their land-use sector but also understand that there are impacts on other sectors - and particularly on the agricultural sector. Whereas most impacts are perceived in the North German Plain in general, some impacts relate to individual regions, as marked in Table 3. 
Table 3 The direct impacts of climate change on regional land use and risks due to climate change as perceived by land-use experts in the North German Plain

\begin{tabular}{|c|c|c|c|}
\hline & Agriculture & Forestry & Water management \\
\hline $\begin{array}{l}\text { Direct impacts of } \\
\text { climate change }\end{array}$ & $\begin{array}{l}\text { - Earlier tillage and catch } \\
\text { crop cultivation } \\
\text { - Changes in agricultural } \\
\text { cultivation cycle } \\
\text { - Impacts on agriculture } \\
\text { primarily water related } \\
\text { - Springtime water shortages } \\
\text { coupled with summer } \\
\text { drought } \\
\text { - Increase in winter } \\
\text { precipitation and } \\
\text { torrential rain events } \\
\text { contributes to (prolonged) } \\
\text { waterlogging } \rightarrow \text { crop } \\
\text { damage and hindering } \\
\text { use of farmland (esp. } \\
\text { Diepholz) } \\
\text { - High surface runoff after } \\
\text { torrential rain particularly } \\
\text { following pronounced } \\
\text { droughts } \rightarrow \text { water only } \\
\text { partially available to } \\
\text { plants } \rightarrow \text { problematic } \\
\text { even when seasonal rain } \\
\text { amounts not reduced } \\
\text { Torrential rain } \\
\text { events } \rightarrow \text { technical } \\
\text { drainage system } \\
\text { capacities stressed } \\
\text { beyond their } \\
\text { limits } \rightarrow \text { problems with } \\
\text { draining agricultural land }\end{array}$ & $\begin{array}{l}\text { - New alien animal species } \\
\text { and pests occur } \rightarrow \text { some } \\
\text { even live through the } \\
\text { (mild) winter } \\
\text { - Considering new } \\
\text { non-indigenous tree } \\
\text { species } \\
\text { - Preservation of regional } \\
\text { autochthonous dispersal } \\
\text { area of the European } \\
\text { beech (esp. Flaeming) } \\
\text { questionable } \\
\text { - Exposed height and } \\
\text { monocultural pine } \\
\text { population } \rightarrow \text { severe } \\
\text { impacts of storm events } \\
\text { (esp. Flaeming) } \\
\text { - Spring } \\
\text { drought } \rightarrow \text { planting of } \\
\text { new trees shifted from } \\
\text { spring to preceding } \\
\text { autumn } \\
\text { - Water scarcity } \rightarrow \text { plant } \\
\text { stress } \rightarrow \text { higher } \\
\text { vulnerability to insect } \\
\text { pests in summer }\end{array}$ & $\begin{array}{l}\text { - Impacts on water bodies } \\
\text { (stagnant water (esp. } \\
\text { Diepholz) and running } \\
\text { water (esp. Uelzen and } \\
\text { Flaeming)) } \rightarrow \text { temporarily } \\
\text { falling dry or notably low } \\
\text { water levels during } \\
\text { summer } \\
\text { - Heads of smaller rivers went } \\
\text { downhill for several meters } \\
\text { (esp. Flaeming) } \\
\text { - Impacts on wetlands and } \\
\text { fens (esp. Diepholz) } \\
\text { temporarily falling dry or } \\
\text { notably low water levels } \\
\text { during the summer } \\
\text { - Rising temperatures and } \\
\text { water scarcity } \rightarrow \text { negative } \\
\text { effects on wetlands and } \\
\text { fens. } \\
\text { - Additional demand for water } \\
\text { in agriculture for increased } \\
\text { irrigation } \rightarrow \text { impacts on } \\
\text { landscape, forests, fens and } \\
\text { wetlands } \\
\text { - Stewponds no longer } \\
\text { drained for } \\
\text { winter } \rightarrow \text { refilled soon } \\
\text { after fishing dry; } \\
\text { consequence of insufficient } \\
\text { rainfall during spring }\end{array}$ \\
\hline $\begin{array}{l}\text { Risks due to } \\
\text { climate change }\end{array}$ & $\begin{array}{l}\text { - Water scarcity at the } \\
\text { beginning of the growing } \\
\text { season } \rightarrow \text { crop failure } \\
\text { and losses } \\
\text { - Waterlogging resulting } \\
\text { from torrential } \\
\text { rain } \rightarrow \text { crop damage and } \\
\text { hinders farmland use } \\
\text { - Water scarcity } \rightarrow \text { reduced } \\
\text { yields } \\
\text { - Increasing demand for } \\
\text { irrigation } \rightarrow \text { impact on } \\
\text { ground water } \\
\text { level } \rightarrow \text { reduced water } \\
\text { availability } \\
\text { - Rising } \\
\text { temperatures } \rightarrow \text { heat } \\
\text { stress for plants }\end{array}$ & $\begin{array}{l}\text { - Drought } \rightarrow \text { losses of tree } \\
\text { vitality } \\
\text { - Drought } \rightarrow \text { Plant stress } \\
\text { due to water } \\
\text { scarcity } \rightarrow \text { higher } \\
\text { vulnerability to insect } \\
\text { pests } \rightarrow \text { forest damage } \\
\text { - Spring } \\
\text { droughts } \rightarrow \text { negative } \\
\text { impacts } \\
\text { - Newly immigrated alien } \\
\text { animal species and pests } \\
\text { live through the } \\
\text { winter } \rightarrow \text { forest damage } \\
\text { - Warmer early } \\
\text { summer } \rightarrow \text { greater } \\
\text { populations of insect } \\
\text { pests (e.g. oak } \\
\text { processionary moth) } \\
\text { greater number of days } \\
\text { with high forest fire } \\
\text { warning levels } \\
\text { (Waldbrandwarnstufe) }\end{array}$ & $\begin{array}{l}\text { - Water budget deficit in } \\
\text { summer } \rightarrow \text { higher water } \\
\text { demands in agriculture for } \\
\text { artificial } \\
\text { irrigation } \rightarrow \text { negative } \\
\text { impacts on ground water } \\
\text { levels }\end{array}$ \\
\hline
\end{tabular}


Table 3 (continued)

\begin{tabular}{|c|c|c|}
\hline Agriculture & Forestry & Water management \\
\hline & $\begin{array}{l}\text { - Increase in extreme } \\
\text { weather events and } \\
\text { storms } \rightarrow \text { windthrow } \\
\text { because of changing } \\
\text { wind directions } \\
\text { - Reduced diversity of tree } \\
\text { species } \rightarrow \text { unpredictable } \\
\text { consequences } \\
\text { - Rising } \\
\text { temperatures } \rightarrow \text { heat } \\
\text { stress for trees }\end{array}$ & \\
\hline
\end{tabular}

Corresponding to general observations with respect to recognising climate change, most respondents answered the more specific question regarding recognition of the direct consequences of climate change for regional land use in the affirmative. On the regional level, an analogous proportion of respondents also perceived climate change impacts on land use.

In general, the impacts perceived by our experts match those in the literature (e.g. Battaglini et al. 2009; Jørgensen and Termansen 2016; Lasch et al. 2002; Gerstengarbe et al. 2003). Thus, similar to the general public (Lorenzoni and Pidgeon 2006), land-use experts are concerned about climate change. Notably, regardless of the experts' sectoral affiliation, the experts focused on climate change impacts on agriculture or on the agricultural landscape, and the answers given in both the questionnaire and during the interviews frequently involve agriculture. This bias in observation might be caused by the visibility of the impact of climate change on the agricultural landscape. In the forests, it is mostly much less pronounced or visible. Considering the permanent and quick changes in agricultural landscapes even within the last year, this bias is understandable. Changes in the forests are not likely to be realised by most people unless extensive thinning or catastrophic events occur (Bell 2001). Furthermore, unplanted parts in a flowering rape field might be easy to recognise, whereas damage to single trees or a group of trees in the woods frequently is not. Thus, in forest development models, hundreds of years are simulated to gain information on the possible impacts of certain activities (e.g. Lasch et al. 2002).

Furthermore, the experts mainly noted water-related climate impacts. Despite the fact that Germany generally has no immediate problems with water availability, the experts mainly noted water-related impacts such as drought or flooding, which shows a high sensitivity towards changes in the water system. Following Huang et al. (2014), this heightened sensitivity is not misguided, as more extreme floods and more frequent extreme droughts are projected in German river basins. Clearly, our results confirm a strong interdependency between agriculture and water management and/or among water, forestry, and agriculture with water as the link, as has previously noted by Barkmann et al. (2015), Falloon and Betts (2010), and Reyer et al. (2012).

\subsection{Opportunities and risks due to climate change}

Most perceived risks can be traced back to, or are projections of, perceived climate-related changes. The results from the questionnaire and the interviews clearly imply that the effects of climate change are generally considered to entail many more risks than opportunities. The answers from the questionnaire and during the interviews frequently have a sectoral focus, 
except that most respondents primarily see risks that are similar to the effects on land use regarding agricultural features.

Nevertheless, some experts expect climate change to bring new opportunities for future land use. Thus, an extended vegetation period and higher mean temperatures might offer new opportunities because plants may grow more rapidly and over a longer time. However, this opinion is primarily provided by land-use experts from the one region (Uelzen) in which irrigation is already used on almost all the arable land. In addition, those experts from Uelzen are involved in agriculture or water management, which is already affiliated with agriculture, and they note that opportunities are constrained by the availability of water for irrigation. If it is not possible to maintain these factors at reasonable levels, the risk of a precipitation deficit counteracts the positive effects of the longer growing season. In addition, the expectations of higher groundwater recharge due to higher precipitation during the winter are also considered an opportunity. Furthermore, it should be emphasised that Europe's regions - and particularly those in Germany - are considered to be privileged regarding climate change compared with other regions in the worlds. Some experts see an increasing potential for tourism in Germany because of the expectation of less rain and higher temperatures.

However, the vast majority of experts responding to the same question about climate change in this study clearly see the risks entailed in climate change impacts. In a sectoral analysis, water scarcity in general and in the spring and summer in particular is the most frequently mentioned and most serious risk noted by experts with consequences primarily for agriculture and forestry (Table 3).

In addition to the interviews, we also inquired in the questionnaire about whether climate change and its resulting impacts primarily entail risks or opportunities for their region. Most respondents clearly see the risks resulting from a changing climate and few see opportunities and/or deny the risks. These results underline the opinions expressed in the interviews.

As proposed by IPCC (2014), climate change might have some benefits. The results showed that in water management, the expected shift of precipitation to winter is considered an opportunity to increase groundwater recharge. This expectation can be derived from Gerstengarbe et al. (2008), who simulated a decreasing summer precipitation and increasing winter precipitation. For agriculture, the experts see opportunities in a prolonged growing season and the increasing temperatures under the condition of a sufficient amount of water during the growing season from either precipitation or irrigation. Thus, on the one hand, prolonging the growing season is projected by Gerstengarbe et al. (2003), but on the other hand, decreased precipitation during the growing season is also projected (Noleppa 2008), which implies a negative impact on plant growth. Furthermore, the previously perceived dry spell in spring is expected to continue into the future, particularly in the Flaeming region (Lüttger 2011). For the Uelzen region, in which more than $90 \%$ of the arable land can be irrigated, the trend of a prolonged growing season is understood positively. To use those opportunities, future water management will surely be an important focus on the predicted future climate, as noted by Reyer et al. (2012).

Nonetheless, climate change and its impact are generally considered a greater risk than an opportunity among the respondents and interviewees of our study, which is also consistent with the findings in the literature (e.g. Lorenzoni and Pidgeon 2006; Battaglini et al. 2009; IPCC 2014). Lorenzoni and Pidgeon (2006) note that the publics' risk perception can inform the management process by highlighting particular concerns; because the results presented from land-use experts are focused on land-use matters, their perspective can also improve the management processes on a more specific level. 
The IPCC (2014) states that current risks are projected to be amplified by climate change. In addition, new risks may be created and, to a lesser extent, climate change may induce some potential benefits. This general statement can be supported by the findings of our study. The long response time of forest ecosystems and their low adaptive capacity (Leemans and Eickhout 2004) mean that the perceived risks must be taken seriouslyparticularly because of the expected severe and wide-ranging negative effects of climate change (Lindner et al. 2010).

Water scarcity is generally considered to be the primary risk among our land-use experts across sectors. For agriculture, these results match those of Battaglini et al. (2009). Because their respondents see drought as the result of climate change and at the same time consider rain as crucial for good quality, drought is thus understood as a risk. Battaglini et al. (2009) also demonstrate a perceived increase of pests and diseases connected with climate change. These results match our results, particularly with respect to the forestry sector. Although the actual pests and diseases may be different, the perception of an increase due to climate change is similar. In forestry, storms, drought, flooding, rising temperatures, and forest fire risk are considered important threats. In particular, the increasing risk of climate change-induced forest fires match simulations (Lindner et al. 2010). In addition, Lasch et al. (2002) also discuss the effects of climate warming because it leads to increased drought stress that can result in negative impacts for forest growth and matches the concrete risks expected by our forestry experts that decreasing precipitation leads to increasing drought stress and calamities. Furthermore, the negative impacts for the long term are confirmed by our experts, whereas for the short-medium term, there might be positive effects on forest growth (Lasch et al. 2011).

\section{Conclusion}

The objective of this paper was to present information from 60 qualitative interviews with land-use experts on the perception of climate change at the regional level. We took an explorative, cross-sectoral approach to show the differences or similarities between the landuse sectors. We were able to show that climate change is perceived at the regional and local levels across the analysed sectors, and that the regional perception of climate change impacts matches the data generated by the scientific community via models and simulations. One advantage of our qualitative approach is that it is very rich in detail and depth on the regional scale and thus adds to results generated by models and simulations. Our results and the literature show the interconnectedness between the sectors. In particular, water availability is the connecting issue across all analysed sectors. Our results also revealed differences among the sectors that, when considered together, present a more complete view on the climate change impacts in total. We also showed that the perceived impacts on land use and the risks and (few) opportunities also match the predicted development for sectors, such as forests. Because of the clearly cross-sectoral perception of climate change impacts and risks on the regional scale, further cross-sectoral approaches should be supported. We agree with OttoBanaszak et al. (2011) that those participatory processes might lead to a shared understanding of the different actor groups and thereby support adaptation. Regional risk management and adaptation processes at the regional level should thus involve regional stakeholders and experts at an early stage. Finally, we like to suggest further research on the integration of experts and stakeholders into the research process (transdisciplinary and qualitative researchZscheischler and Rogga 2015) because - though challenging - it might improve adaptation 
processes by bringing real-world viewpoints and demands into the research process and thereby supporting the public's acceptance of research results on climate change.

Acknowledgements This work has been performed in the context of the NaLaMa-nT project funded by the German Ministry of Education and Research (grant no. 033L029K). The authors would like to thank the four regional coordinators in the model regions and the regional experts for their support. We also thank Prof. Dr. P.C. Werner from the Potsdam Institute for Climate Impact Research (PIK) for providing the regional climate data, Robert Nuske for providing the map for the chapter "case study area" and two anonymous reviewers for their helpful comments.

Open Access This article is distributed under the terms of the Creative Commons Attribution 4.0 International License (http://creativecommons.org/licenses/by/4.0/), which permits unrestricted use, distribution, and reproduction in any medium, provided you give appropriate credit to the original author(s) and the source, provide a link to the Creative Commons license, and indicate if changes were made.

\section{References}

Adger et al (2009) Are there social limits to adaptation to climate change? Clim Chang 93:335-354. doi:10.1007 /s10584-008-9520-Z

Agho K, Stevens G et al (2010) Population risk perceptions of global warming in Australia. Environ Res 110: 756-763. doi:10.1016/j.envres.2010.09.007

Akerlof et al (2010) Public perceptions of climate change as a human health risk: surveys of the United States. Canada and Malta Int J Environ Res Public Health 2010(7):2559-2606. doi:10.3390/ijerph7062559

Arnell NW, Tompkins EL, Adger WN (2005) Eliciting information from experts on the likelihood of rapid climate change. Risk Anal 25:6. doi:10.1111/j.1539-6924.2005.00689.x

Babby ER (2012) The practice of social research, 13th edn. Wadsworth Publishing, Belmont

Barkmann T, Siebert R, Lange A (2015) Climate change adaptation and mitigation in agriculture, forestry and water management at the regional scale: a case study from the North German Plain. Outlook on Agriculture 44(4):257-265. doi:10.5367/oa.2015.0220

Battaglini et al (2009) European winegrowers' perceptions of climate change impact and options for adaptation. Reg Environ Chang 9:61-73. doi:10.1007/s10113-008-0053-9

Bell S (2001) Landscape pattern, perception and visualisation in the visual management of forests. Landscape Urban Plan 54(1-4):210-211. doi:10.1016/S0169-2046(01)00136-0

Bindi M, Olesen JE (2011) The responses of agriculture in Europe to climate change. Reg Environ Chang 11(Suppl 1):151-158. doi:10.1007/s10113-010-0173-x

Cresswell JW (2009) Research design: qualitative, quantitative, and mixed methods approaches, 3th edn. SAGE Publications, Thousand Oaks

Cubasch U, Kadow C (2011) Global climate change and aspects of regional climate change in the BerlinBrandenburg region. Erde 142:3-20

Doria MF, Boyd E, Tompkins EL, Adger WN (2009) Using expert elicitation to define successful adaptation to climate change. Environ Sci Pol 12:810-819. doi:10.1016/j.envsci.2009.04.001

Engels et al (2013) Public climate-change scepticism, energy preferences and political participation. Glob Environ Chang 23:1018-1027. doi:10.1016/j.gloenvcha.2013.05.008

Falloon P, Betts R (2010) Climate impacts on European agriculture and water management in the context of adaptation and mitigation - the importance of an integrated approach. Sci Total Environ 408:5667-5687. doi:10.1016/j.scitotenv.2009.05.002

Gerstengarbe F-W, Werner PC (2007) Der rezente Klimawandel [The recent climate change]. In: Endlicher W, Gerstengarbe F-W (ed) Der Klimawandel-Einblicke, Rückblicke und Ausblicke [Climate change-insights, retrospects and prospects], Potsdam, Germany, pp 34-43

Gerstengarbe F-W, Badeck F, Hattermann F et al (2003) PIK Report No.83 Studie zur klimatischen Entwicklung im Land Brandenburg bis 2055 und deren Auswirkungen auf den Wasserhaushalt, die Forst- und Landwirtschaft sowie die Ableitung erster Perspektiven [Research study on the climatic development in the state of Brandenburg till 2055 and impacts on water budget, forestry, agriculture and a first impact assessment]. Potsdam, Germany

Gerstengarbe et al (2008) 1 Klimaprojektion für Ostdeutschland. In: Wechsung et al (ed): PIK Report No. 112 Die Ertragsfähigkeit ostdeutscher Ackerflächen unter Klimawandel, Potsdam, Germany, pp 2-17. doi:10.2312/PIK.b103-pik1129 
Hansen J, Sato M, Ruedy R (2012) Perception of climate change. PNAS. doi:10.1073/pnas.1205276109

Huang S, Krysanova V, Hattermann F (2014) Projections of climate change impacts on foods and droughts in Germany using an ensemble of climate change scenarios. Reg Environ Chang. doi:10.1007/s10113-014-0606-Z

IPCC (2013) Summary for policymakers. In: Stocker TF, Qin D, Plattner G-K et al (ed) Climate Change 2013: the physical science basis - contribution of Working Group I to the Fifth Assessment Report of the Intergovernmental Panel on Climate Change. Cambridge University Press, Cambridge and New York

IPCC (2014) Summary for policymakers. In: Field CB, Barros VR, Dokken DJ et al (ed) Climate Change 2014: impacts, adaptation, and vulnerability. Part A: global and sectoral aspects. Contribution of Working Group II to the Fifth Assessment Report of the Intergovernmental Panel on Climate Change. Cambridge University Press, Cambridge and New York, pp. 1-32

Jørgensen SL, Termansen M (2016) Linking climate change perceptions to adaptation and mitigation action. Clim Chang. doi:10.1007/s10584-016-1718-x

Kätzel R, Höppner K (2011) Adaptation strategies in forest management under the conditions of climate change in Brandenburg. Folia Forestalia Polonica, series A 53(1):43-51

Kvaløy B, Finseraas H, Listhaug O (2012) The publics' convern for global warming: a cross-national study of 47 countries. J Peace Res 49(1):11-22. doi:10.1177/0022343311425841

Lange A, Siebert R, Barkmann T (2015) Sustainability in land management: an analysis of stakeholder perceptions in rural Northern Germany. Sustainability, Vol 7:683-704

Lange A, Siebert R, Barkmann T (2016) Incrementality and regional bridging as instruments for promoting stakeholder participation in land use management. Experiences from a participatory guiding principle process in Northern Germany. Soc Nat Resour 29:868-879. doi:10.1080/08941920.2015.1122135

Lasch P, Lindner M, Erhard M et al (2002) Regional impact assessment on forest structure and functions under climate change - the Brandenburg case study. Forest Ecol Manag 162:73-86

Lasch et al (2011) Expertise 4 "Klimawandel und Waldentwicklung der Region Havelland-Fläming” [Expertise 4 "Climate change and forest development in the Havelland-Flaeming region"]. In Lüttger et al PIK Report No. 121 Klimawandel in der Region Havelland-Fläming [Climate Change in the Havelland-Flaeming region]. Potsdam, Germany, pp 115-175

Laukkonen J, Blanco PK, Lenhart J et al (2009) Combining climate change adaptation and mitigation measures at the local level. Habitat Int 33:287-292. doi:10.1016/j.habitatint.2008.10.003

Leemans R, Eickhout B (2004) Another reason for concern: regional and global impacts on ecosystems for different levels of climate change. Glob Environ Chang 14:219-228. doi:10.1016/j.gloenvcha.2004.04.009

Lindner et al (2010) Climate change impacts, adaptive capacity, and vulnerability of European forest ecosystems. For Ecol Manag 259:689-709. doi:10.1016/j.foreco.2009.09.023

Lorenzoni I, Pidgeon NF (2006) Public views on climate change: European and USA perspectives. Clim Chang 77:73-95. doi:10.1007/s10584-006-9072-z

Lorenzoni I, Nicholson-Cole S, Whitmarsh L (2007) Barriers perceived to engaging with climate change among the UK public and their policy implications. Glob Environ Chang 17:445-459. doi:10.1016/1. gloenvcha.2007.01.004

Lüttger A (2011) Expertise 3 "Klimawandel und Landwirtschaft in der Region Havelland-Fläming” [Expertise 3 "Climate change and agriculture in the Havelland-Flaeming region"]. In Lüttger A, Gerstengarbe F-W, Gutsch M et al PIK Report No. 121 Klimawandel in der Region Havelland-Fläming [Climate Change in the Havelland-Flaeming region]. Potsdam, Germany, pp 89-113

Mayring P (2000) Qualitative Inhaltsanalyse. Grundlagen und Techniken [Qualitiative content analysis. Basics and techniques]. Deutscher Studien Verlag, Weinheim

Meuser M, Nagel U (1991) ExpertInneninterviews - vielfach erprobt, wenig bedacht. Ein Beitrag zur qualitativen Methodendiskussion. In: Garz D, Kraimer K (eds) Qualitativ-empirische Sozialforschung. Konzepte, Methoden, Analysen [Qualitative-empirical social research. Concepts, methods, analysis]. Westdeutscher Verlag, Opladen, pp 441-471

Miles MB, Huberman AM (1994) Qualitative data analysis. In an expanded sourcebook, 2nd edn. Sage, London

Noleppa S (2008) Klimaänderungen und weitere globale Entwicklungen: langfristige Chancen und Risiken für die ostdeutsche Landwirtschaft. In: Wechsung F, Gerstengarbe F-W, Lasch P, Lüttger A (ed) PIK Report No. 112 Die Ertragsfähigkeit ostdeutscher Ackerflächen unter Klimawandel, Potsdam, Germany, pp 45-55. doi:10.2312/PIK.b103-pik1129

Otto-Banaszak et al (2011) Different perceptions of adaptation to climate change: a mental model approach applied to the evidence from expert interviews. Reg Environ Chang 11:217-228. doi:10.1007/s10113-0100144-2

Patton MQ (2002) Qualitative research \& evaluation methods, 3rd edn. Sage Publications, Thousand Oaks

Pidgeon N (2012) Public understanding of, and attitudes to, climate change: UK and international perspectives and policy. Clim Pol 12(sup01):S85-S106. doi:10.1080/14693062.2012.702982 
Poortinga W, Spence A, Whitmarsh L, Capstick S, Pidgeon NF (2011) Uncertain climate: an investigation into public scepticism about anthropogenic climate change. Glob Environ Chang 21:1015-1024. doi:10.1016/j. gloenvcha.2011.03.001

Rannow S, Loibl W, Greiving S, Gruehn D, Meyer BC (2010) Potential impacts of climate change in Germanyidentifying regional priorities for adaptation activities in spatial planning. Landscape Urban Plan 98:160171. doi:10.1016/j.landurbplan.2010.08.017

Ratter BMW, Philipp KHI, von Storch H (2012) Between hype and decline: recent trends in public perception of climate change. Environ Sci Pol 18:3-8. doi:10.1016/j.envsci.2011.12.007

Reyer et al (2012) Climate change adaptation and sustainable regional development: a case study for the Federal State of Brandenburg, Germany. Reg Environ Chang 12:523-542. doi:10.1007/s10113-011-0269-y

Rounsevell MDA, Reay DS (2009) Land use and climate change in the UK. Land Use Policy 26:160-169. doi:10.1016/j.landusepol.2009.09.007

Scruggs L, Benegal S (2012) Declining public concern about climate change: can we blame the great recession? Glob Environ Chang 22:505-515. doi:10.1016/j.gloenvcha.2012.01.002

Stoutenborough JW, Sturgess SG, Vedlitz A (2013) Knowledge, risk, and policy support: public perceptions of nuclear power. Energy Policy 62:176-184. doi:10.1016/j.enpol.2013.06.098

Taylor A, Bruine de Bruin W, Dessai S (2014) Climate change beliefs and perceptions of weather-related changes in the United Kingdom. Risk Anal. doi:10.1111/risa.12234

Wheeler S, Zuo A, Bjornlund H (2013) Farmers' climate change beliefs and adaptation strategies for a water scarce future in Australia. Glob Environ Chang 23:537-547. doi:10.1016/j.gloenvcha.2012.11.008

Whitmarsh L (2011) Scepticism and uncertainty about climate change: dimensions, determinants and change over time. Glob Environ Chang 21:690-700. doi:10.1016/j.gloenvcha.2011.01.016

Zimmermann A, Maennling C (2007) Mainstreaming participation. Multi-stakeholder management: tools for stakeholder analysis. GTZ, Eschborn

Zscheischler J, Rogga S (2015) Transdisciplinarity in land use science-a review of concepts, empirical findings and current practices. Futures 65:28-44. doi:10.1016/j.futures.2014.11.005 